\title{
Two Ideas of Human Nature: Giovanni Pico della Mirandola and Thomas à Kempis
}

\section{Thomas MacGrath}

In this essay I will examine and compare the idea of human nature in the minds of Christian humanists during the Renaissance to that of late Medieval Christian mystics. Leslie Stevenson succinctly defines what can be meant by theories of human nature. Stevenson wrote that the study of human nature can include making "general claims" about humanity and the human condition, but also that it describes the flaws in humanity. By studying theories of human nature, one can be exposed to what the shortcomings of humanity have led to in the past. Stevenson wrote that a theory of human nature can offer " a prescription or ideal of how human life should best be lived, typically offering guidance to individuals and human societies."

The Oration on the Dignity of Man, written by Giovanni Pico della Mirandola (Pico) provides an insight into the mind of a Renaissance humanist, while The Imitation of Christ, written by Thomas à Kempis, illustrates the thought process that was characteristic of a late Medieval Christian mystic. Pico believed that humans are a great

miracle and it is within their nature and capabilities to become something great in the world, something just below the level of God. ${ }^{2}$ À Kempis held the belief that human nature was corrupted by the Fall of Man in the Garden of Eden. It can be found in his writings that he believed human nature is something that is detrimental to the individual and can only be controlled by the grace of God. ${ }^{3}$

The different points of view on human nature found in the writing of Pico and à Kempis can be traced to the sources of their inspiration and also to the different movements they belonged to. In writing The Imitation of Christ, à Kempis drew his inspiration only from the Bible. Pico, like many other Renaissance humanists, looked for truth about human nature not only in the Bible but also by studying other classical works such as the ancient Greeks and Arabs. The key difference in the views held by Pico and à Kempis on human nature is that Pico believed that humans, through exercising their own will, could overcome the sinful, corrupt elements of their nature and bring themselves to a close level of communion with the God who created them. ${ }^{4}$ It can be seen in the writing of à Kempis that he held a view opposite to that of Pico, one in which humans are incapable of overcoming their sinful nature outside of being chosen by God to have His grace present in their lives. ${ }^{5}$ It is nothing of human will, in the view of à Kempis, that can help a person overcome the corrupt nature he believed to affect the essence of every human being.

The late medieval movement known as the devotio moderna educated Thomas à Kempis. The devotio moderna was made up of religious communities known as the Brothers

\footnotetext{
${ }^{1}$ Leslie Stevenson and David L. Haberman, Ten Theories of Human Nature (New York: Oxford University Press, 2009), 1-2.

${ }^{2}$ Giovanni Pico della Mirandola, Oration on the Dignity of Man (New York: Cambridge University Press, 2012).

${ }^{3}$ Thomas à Kempis, The Imitation of Christ (Chicago: Moody Press, 1958).

${ }^{4}$ Pico, The Oration, 121.

${ }^{5}$ Thomas à Kempis, The Imitation of Christ (London: Penguin Books, 2013), 219.
} 
and Sisters of the Common Life, who were groups of laypeople devoted to the study of scripture and copying various religious manuscripts. There were groups of Augustinian monks who belonged to the devtio moderna as well, which à Kempis would eventually belong to. ${ }^{6}$

The works of Augustine had great influence over many Western mystics such as à Kempis. Augustine saw human nature, as described by Henry Chadwick: "[as being] held down by a dead weight of personal and collective egotism; in other words by what Augustine called 'original sin'."7 The influence of Augustine's ideas on human nature can be seen throughout à Kempis' work and can help explain why he interpreted the account of the Fall of man in the book of Genesis in the way that he did.

The Imitation of Christ has been referred to as the manifesto of the devotio moderna. ${ }^{8}$ The Imitation's contents reflect the virtues of patience, humility and spiritual devotion that were valued by à Kempis and other members of the movement. ${ }^{9}$ The following passage from The Imitation reflects something of what à Kempis wanted his readers to take away from reading the book. He wrote: "Learned words do not make anyone wise or holy; it is a good life which draws us closer to God. I would rather feel deep sorrow than be able to define it."10 The Imitation was written as a call for individuals to reflect on who they are on their interior. As can be seen in the above passage from The Imitation, it was not an intellectual prowess that à Kempis and others in the devotio moderna were pursuing, but rather an inward transformation of the individual.

If The Imitation of Christ was the manifesto for the devotio moderna, the same could be said in regard to The Oration on the Dignity of Man for Renaissance humanism. Renaissance humanists such as Pico and his primary teacher, Marsilio Ficino, believed in a concept known as "prisca theologia" or ancient theology. This doctrine holds that God revealed religious truths not only to the ancient Jews but also to the founders of each ancient religious tradition. ${ }^{11}$ These ideas are present throughout Pico's work and can help explain his idea of human nature.

Pico's goals in writing on human nature were considerably different than those of Thomas à Kempis. Pico was on a quest, like many Renaissance humanists, to combine the different religions of the world to form a new theology that would prove the presence of Christian truths in all religions. ${ }^{12}$ In this pursuit to combine the truths of all ancient religious traditions, Pico likely developed a fundamentally different idea of human nature than a late medieval mystic like Thomas à Kempis.

The opening lines of the Oration on the Dignity of Man provide a good example of how Renaissance humanists used ancient sources other than the Bible in their pursuit of truth and knowledge on the subject of human nature. The first few verses of the Oration

\footnotetext{
${ }^{6}$ Max von Habsburg, Introduction to The Imitation of Christ by Thomas à Kempis (London: Penguin Books, 2013), xvi-xvii.

${ }^{7}$ Henry Chadwick: Augustine: A Very Short Introduction ( New York: Oxford University Press, 2001), 3.

8 von Habsburg, Introduction to The Imitation of Christ, xvi.

${ }^{9}$ Ibid, xviii.

10 à Kempis, The Imitation (2013), 5.

${ }^{11}$ Charles Nauert, "Re-thinking Christian Humanism," in Interpretations of Renaissance Humanism, ed. Angelo Mazzocco ( Boston: Brill Academic Publishers, 2006), 165.

${ }^{12}$ James Hankins, "Religion and the Modernity of Renaissance Humanism," in Interpretations of Renaissance Humanism, ed. Angelo Mazzocco ( Boston: Brill Academic Publishers, 2006), 143-144.
} 
inform the reader that Pico is consulting ancient Greek and Arab texts, as well as the Bible. ${ }^{13}$ Pico cites Abadallah the Saracen, Hermes Trismegistus, and David of the Bible in these verses. The image of man presented by Pico in the Oration nicely illustrates how Christian humanists during the Renaissance infused classical sources other than the Bible into their perspectives of human nature. Pico referred to humans as having an "indeterminate image" which contradicts the idea of humans being created in the image of God found in Genesis 1:26. ${ }^{14}$

Some insight as to where Pico may have developed this philosophy is illuminated further into the Oration. Pico quotes a saying of the ancient Chaldeans that "Man is by nature diverse, multiform and inconstant." 15 According to Pico, humans have the ability to choose which pursuits to follow in life. He wrote: "The Father infused in man, at his birth, every sort of seed and all sprouts of life." ${ }^{16}$ God planted the "seeds" in humans in Pico's view, but it was up to the individual which seeds would be cultivated. In the ideas presented by Pico in the Oration every human had the potential to become an angel or a son of God. This potential can only be achieved by cultivating the "intellectual" seeds that have been planted in humans by God. ${ }^{17}$

Pico believed that a great purpose of humanity was to contemplate the Earth that God had created. He wrote: "But when the work was finished, the Craftsman still longed for there to be someone to ponder the meaning of such a magnificent achievement, to love its beauty and to marvel at its vastness." ${ }^{18}$ It was through the contemplation of the meaning of God's creation that Pico thought the intellectual seeds of a human could be cultivated, therefore elevating them to a level just below that of God. Pico reinforced how important he thought the art of contemplation was later in the Oration. He wrote:

If you see a philosopher discerning things with right reason, worship him, for he is not an earthly creature, but divine. If you see a pure contemplator, oblivious to his body and absorbed in the recesses of his mind, this is neither an earthly or a heavenly creature: this is still a more eminent spirit, clothed in human flesh. Who, then, will not admire man? ${ }^{19}$

Humans are worthy of admiration, Pico wrote here, but only when allowing themselves to contemplate their surroundings that they have been placed in by God. Humans also have the potential, in Pico's mind, to become "brute animal[s]" if they choose to cultivate the seeds of their senses. ${ }^{20}$

In examining the writing of Pico found in the Oration, the conclusion can be made that he believed it was through the careful contemplation of one's surroundings that would allow a person to be close to God and suppress other, less desirable characteristics of one's nature. Pico was in pursuit to bring all sources of knowledge and religion together to

\footnotetext{
13 Pico, Oration, 109.

14 Ibid, 117.

15 Ibid, 133.

16 Ibid, 121.

17 Pico, Oration, 121.

18 Ibid,113.

19 Ibid, 133.

${ }^{20}$ Ibid, 121.
} 
become one unified body of knowledge and theology. ${ }^{21}$ In his writing, Pico sought to include aspects of many different worldviews in his philosophies. There are ideas found in Pico's writing that allow for an individual identity to exist. In Pico's view human beings choose which parts of their nature they will allow to grow, and by that means they are able to determine what level of communion with God they will achieve.

In the minds of late medieval Christian mystics such as Thomas à Kempis, the outlook on human nature was somewhat different than a Renaissance humanist. Ursula King defines a mystic as " a person who is deeply aware of the powerful presence of the divine Spirit: someone who seeks, above all, the knowledge and love of God and who experiences to an extraordinary degree the profoundly personal encounter with the energy of divine life."22 The acclaim that has followed à Kempis' great work, The Imitation of Christ, certainly suggests that à Kempis was a man who has been considered to be in pursuit of the knowledge and love of God. In a foreword to a 1958 edition of The Imitation, the president of the Moody Bible Institute, S. Maxwell Coder, wrote: "Countless believers have found that these pithy sayings drew them closer to the Lord Jesus Christ in submission to His will and in victory over the lower nature." 23 The "lower nature" referred to by Coder is the idea of human nature taken from the Bible. As à Kempis seems to have interpreted it, the book of Genesis describes human nature as being permanently corrupted by the Fall of man.

In chapters fifty-four through fifty-six of the third book of the Imitation, citing only from the Bible, à Kempis wrote on human nature and how it may be overcome through the grace of God. It is clear from these chapters in The Imitation of Christ that mystics such as à Kempis did not see the nature of human beings to have the same potential as Renaissance humanists like Pico. In chapter fifty-four of The Imitation's third book, à Kempis makes a contrast between nature and grace. What à Kempis is referring to here is the sinful, selfseeking nature he believed all humans possess and the grace of God. Robert Jeffery, who translated a 2013 edition of The Imitation, defines à Kempis' idea of grace as: " The activity of God in the lives of people. It is a freely given and undeserved gift that allows us to overcome our lower nature." 24

One of the shortcomings of human nature can be seen in à Kempis' description of the selfishness of humans. He wrote: " Nature strives for its own advantage, and considers what profit it may reap by another. Grace considers not what is profitable and useful to itself, but rather what may be for the good of many." 25 On the subject of the selfishness of human nature, à Kempis went on, writing: "Nature is covetous, more willingly receives than gives, and loves to have things private and its own. But grace is kind and openhearted, shuns private interest, is content with a few things, judges that "it is more blessed to give than to receive" (Acts 20:35)."26

\footnotetext{
${ }^{21}$ James Bruce Ross and Mary Martin McLaughlin, eds., The Portable Renaissance Reader ( New York: Penguin Books, 1981), 55.

${ }^{22}$ Ursula King, Christian Mystics: Their Lives and Legacies throughout the Ages (New Jersey: Hidden Spring, 2001), 3.

${ }^{23}$ S. Maxwell Coder, Foreword to The Imitation of Christ by Thomas à Kempis (Chicago: Moody Press, 1958), 4.

${ }^{24}$ Robert Jeffery, Notes On The Translation of The Imitation of Christ by Thomas à Kempis (London: Penguin Books, 2013), xxxviii.

25 à Kempis, The Imitation( 1958), 201.

${ }^{26}$ Ibid, 202.
} 
In reading these passages from the Imitation, the reader is given the impression that human nature is not something to be celebrated, but rather contended with through the grace of God. According to the Imitation, the grace of God is found through a faith in His son, Jesus Christ. à Kempis acknowledges the importance of a pursuit of the truth that he believes is the grace of God and following the ways of Jesus Christ: "Ye shall know the truth and the truth shall make you free (John 8: 31, 32.)"27 The truth that the Gospel of John is referring to in these passages is the grace of God, revealed through Jesus Christ. à Kempis cites another famous verse from the Gospel of John, quoting the words attributed to Christ: "I am the way, the truth and the life," ( John 14: 6)." ${ }^{28}$ It is through following the ways of Jesus Christ that à Kempis believes a person can be set free from their sinful nature. à Kempis demonstrates that he did not assume that a person could achieve such enlightenment without Divine intervention as he wrote a prayer: " 0 Lord Jesus, forasmuch as Thy way was narrow and despised by the world, grant me grace to imitate Thee.." ${ }^{29}$ This idea of grace is found alongside that of human nature in à Kempis' writing, presented as a means to overcome the inherently evil and self-seeking nature of a human being. He wrote: "grace is the mistress of truth, the teacher of discipline, the light of the heart, the solace of affliction, the driver-away of sorrow, the expeller of fear, the nurse of devotion..." ${ }^{30}$

The philosophies of Thomas à Kempis do not allow much room for an individual identity. It is evident from his writing that he believed human nature should be controlled and replaced by the grace of God. The grace à Kempis wrote of can be found through putting one's faith in the one believed to be the Son of God, Jesus Christ, rather than in their own sinful nature. A faith in Christ would replace one's own sinful nature by the grace of God, and this is where à Kempis felt an individual should try to seek identity. As the title of his book suggests, an imitation of Christ is the way in which a person should live their life. According to à Kempis, it is through studying the teachings of Christ that a person will truly find life, as he wrote His words in chapter fifty-six of The Imitation: "If you wish to enter into Life, keep my commandments." 31 At the beginning of the same chapter, à Kempis elaborates through citing the gospel of Matthew as to how a person should seek to follow Jesus Christ. He wrote: " My child, you will be able to enter into My life in so far as you are willing to forsake yourself." ${ }^{2}$ à Kempis thought an individual should be willing to abandon the self-seeking, sinful nature that he believed was inherent in every human being. Knowing the commands of Christ and following those ways, he believed, would allow one to be free from their corrupt identity as an inherently sinful human and truly experience a life free from sin through following Jesus Christ.

There are some similarities that can be found in the writings of Pico and Thomas à Kempis. Both parties contested that humans are indeed a creation of God who were placed on the Earth to fulfill distinct purposes. Both à Kempis and Pico were of the opinion that humans could achieve a certain level of communion with God. These two thoughtful authors did, however, have considerably different opinions as to how such an achievement

\footnotetext{
27 à Kempis, The Imitation (1958), 207.

${ }^{28}$ Ibid,207.

${ }^{29}$ Ibid, 208.

${ }^{30}$ Ibid, 206.

31 à Kempis, The Imitation ( 2013), 220.

32 Ibid,220.
} 
could be made. Pico thought that humans have it within themselves to choose which aspects of their nature is manifested; he believed it is up to the individual to choose between the good and evil in their nature. à Kempis thought that it was nothing outside of grace, or the action of God in the lives of humans, that could allow a person to become anything outside of sinful during their time on Earth. These two men were both in pursuit of what they thought was the knowledge and love of God, though the path to such is considerably narrower in the philosophies of Thomas à Kempis than in those of Giovanni Pico della Mirandola. 


\section{Bibliography}

à Kempis, Thomas. The Imitation of Christ. Chicago: Moody Press, 1958.

à Kempis, Thomas. The Imitation of Christ. London: Penguin Books, 2013.

Chadwick, Henry. Augustine: A Very Short Introduction. New York: Oxford University Press, 2001.

Coder, S. Maxwell . Foreword to The Imitation of Christ by Thomas à Kempis. Chicago: Moody Press, 1958.

della Mirandola, Giovanni Pico. Oration on the Dignity of Man. New York: Cambridge University Press, 2012.

Hankins, James. "Religion and the Modernity of Renaissance Humanism." in Interpretations of Renaissance Humanism, edited by Angelo Mazzocco, 137-155. Boston: Brill Academic Publishers, 2006.

Jeffery, Robert. Notes On The Translation of The Imitation of Christ by Thomas à Kempis. London: Penguin Books, 2013.

Nauert, Charles. "Re-thinking Christian Humanism." In Interpretations of Renaissance Humanism, edited by Angelo Mazzocco, 155-181. Boston: Brill Academic Publishers, 2006.

Ross, James Bruce and McLaughlin, Mary Martin, eds. The Portable Renaissance Reader. New York: Penguin Books, 1981.

Stevenson, Leslie and Haberman, David L. Ten Theories of Human Nature. New York: Oxford University Press, 2009.

von Habsburg, Max. Introduction to The Imitation of Christ by Thomas à Kempis. London: Penguin Books, 2013. 